\title{
PENINGKATAN KEMAMPUAN SENI DALAM PEMBELAJARAN MELUKIS DENGAN LILIN ANAK KELOMPOK A DI TK NEGERI KEPANJENLIDUL I KOTA BLITAR
}

\author{
YUSTINA DWI RETNO ARIANIE \\ TK Negeri Kepanjenkidul I Kota Blitar \\ Email: arianiyustina174@gmail.com
}

\begin{abstract}
ABSTRAK
Tujuan dari penelitian ini adalah untuk memperoleh data tentang kemampuan seni anak sebelum dilakukan tindakan, penerapan kegiatan peningkatan kemampuan seni dalam pembelajaran melukis dengan lilin, pengumpulan data pada kemampuan seni anak sesudah dilakukan tindakan dan untuk mengetahui adanya perbedaan kemampuan seni anak sebelum dan sesudah dilakukan tindakan pada anak kelompok A di TK Negeri Kepanjenkidul I Kota Blitar. Penelitian tindakan kelas ini menggunakan model Kemmis dan Mc. Taggart. Penelitian ini dilaksanakan selama 2 siklus, dan setiap siklus terdiri dari 2 pertemuan, dimana masingmasing siklus terdiri dari tahap-tahap sebagai berikut: perencanaan, pelaksanaan tindakan, pengamatan dan refleksi. Subyek penelitian adalah anak kelompok A yang berjumlah 15 orang anak, 9 anak laki-laki dan 6 anak perempuan. Instrument yang digunakan adalah lembar observasi dan dokumentasi yang terdiri dari beberapa indikator. Data yang terkumpul dianalisis menggunakan data kuantitatif. Untuk teknik pengumpulan data yang digunakan dalam penelitian ini adalah melakukan penilaian unjuk kerja menggunakan metode demonstrasi. Adapun hasil analisis menunjukkan bahwa dalam meningkatkan kemampuan seni melukis peserta didik secara kuantitatif terjadi peningkatan dari pra tindakan sebesar 31,8\%, tindakan siklus I sebesar. 57,8\%, tindakan siklus II sebesar 81,5\%. dengan ketuntasan klasikal sebesar $75 \%$. Dengan demikian dapat dinyatakan bahwa peningkatan kemampuan seni pembelajaran melukis dengan lilin anak kelompok A di TK Negeri Kepanjenkidul I Kota Blitar sudah meningkat.
\end{abstract}

Kata Kunci: Kemampuan Seni, Pembelajaran, Melukis Lilin.

\section{ABSTRACT}

The purpose of this study was to obtain data on children's artistic abilities before the action was taken, the application of art ability improvement activities in learning to paint with wax, collecting data on children's artistic abilities after the action was taken and to find out the differences in children's artistic abilities before and after the action was taken. group A children in Kepanjenkidul I Kindergarten in Blitar City. This classroom action research uses the Kemmis and Mc. Taggart. This research was carried out for 2 cycles, and each cycle consisted of 2 meetings, where each cycle consisted of the following stages: planning, implementing actions, observing and reflecting. The research subjects were group A children, which consisted of 15 children, 9 boys and 6 girls. The instrument used is an observation sheet and documentation consisting of several indicators. The collected data were analyzed using quantitative data. The data collection technique used in this study is to assess performance using the demonstration method. The results of the analysis show that in improving students' painting skills quantitatively, there is an increase from the pre-action by $31.8 \%$, the first cycle of action by. $57.8 \%$, the second cycle of action is $81.5 \%$. with a classical completeness of $75 \%$. Thus, it can be stated that the improvement in the art of learning to paint with wax for group A children at the Kepanjenkidul I Kindergarten in Blitar City has increased.

Keywords: Art Ability, Learning, Painting Candles.

\section{PENDAHULUAN}

Pendidikan anak usia dini adalah jenjang pendidikan sebelum memasuki pendidikan dasar yang merupakan suatu upaya pembinaan ditujukan bagi anak sejak lahir sampai dengan usia 6 
tahun melalui pemberian rangsangan pendidikan untuk membantu pertumbuhan dan perkembangan jasmani maupun rohani agar anak memiliki kesiapan untuk memasuki jenjang pendidikan yang lebih lanjut, yang diselenggarakan pada jalur formal dan informal.

Pendidikan Taman Kanak-kanak menurut Undang- Undang RI Nomor 20 Tahun 2003 tentang Sistem Pendidikan Nasional Pasal 28, ayat 3 merupakan pendidikan anak usia dini pada jalur pendidikan formal yang bertujuan membantu anak didik mengembangkan berbagai potensi, baik fisik maupun psikis yang meliputi moral dan nilai agama, sosial emosional, kemandirian, kognitif, bahasa, fisik/motorik dan seni untuk siap memasuki sekolah dasar. Anak usia 4-6 tahun merupakan bagian dari anak usia dini yang secara terminologi disebut sebagai anak usia prasekolah atau taman kanak-kanak.

Menurut Suyanto (2005) mengatakan bahwa perkembangan kecerdasan anak pada masa ini mengalami peningkatan dari $50 \%$ menjadi $80 \%$. Hal ini menunjukkan pentingnya upaya pengembangan seluruh potensi anak diusia prasekolah karena pada usia tersebut anak mengalami masa peka,yaitu masa terjadinya pematangan fungsi-fungsi fisik dan psikis yang siap merespons stimulus yang diberikan oleh lingkungan, serta untuk meletakkan dasar pertama dalam mengembangkan seluruh potensi anak, termasuk minat dan bakat dalam bidang seni.

Menurut Moeslichatoen (2004) berpendapat bahwa melalui kegiatan bermain anak dapat mengembangkan kreatifitasnya yaitu melakukan kegiatan yang mengandung kelenturan, memanfaatkan imajinasinya untuk berekspresi. Ada beberapa kegiatan melalui penilaian yang dapat mengembangkan kreatifitasnya seperti menggambar (drawing), kegiatan painting (melukis), kegiatan printing (mencetak), kegiatan college (menempel), kegiatan modeling (membentuk).

Menurut Sumanto (2005) arti melukis adalah proses mengungkapkan ide atau gagasan melalui unsur pigmen atau warna di atas kanvas, dalam hal ini warna merupakan unsur yang utama dalam karya lukisan. Menurut Muharam (1993) melukis adalah membuat gambar, melukis dengan tiruan barang (orang, binatang, dan tumbuhan) yang dibuat dengan cat, tinta, potret dengan gambar angan-angan dan lukisan yang dikhayalkan.

Menurut Hajar Pamadhi (2008) menyebutkan ada 9 manfaat melukis bagi perkembangan anak TK, antara lain :1) Melukis sebagai media mencurahkan perasaan, 2) Melukis sebagai alat bercerita (Bahasa visual/bentuk), 3) Melukis berfungsi sebagai alat bermain, 4) Melukis dapat melatih ingatan, 5) Melukis dapat melatih berpikir komprehensif (menyeluruh), 6) Melukis sebagai sublimasi perasaan, 7) Melukis dapat melatih keseimbangan, 8) Melukis dapat melatih kreativitas anak.

Kegiatan melukis merupakan kegiatan yang dilakukan anak dengan menggunakan permainan warna serta garis yang disusun dalam suatu media baik itu kertas, kanvas, maupun dinding yang luas. Melukis merupakan gambaran yang menceritakan pengalamannya dan di dalamnya terdapat seribu makna yang

tidak dipunyai oleh siapapun. Melukis di sekolah biasanya dilakukan dengan menggunakan peralatan standar, antara lain menggambar dengan pensil, pastel, cat air, atau lainnya. Ini dapat dilihat ketika guru di dalam proses pembelajaran guru memberikan materi melukis selalu monoton dan kurang kreatif sehingga membuat anak menjadi jenuh dan malas untuk mengikuti kegiatan tersebut. Oleh karena itu agar kegiatan melukis ini menarik minat anak dan sifatnya menyenangkan maka sebaiknya kita mencoba menggunakan hal baru sebagai bahan melukis yaitu dengan menggunakan lilin dan pewarna cair. Semua bahan tersebut dapat kita peroleh di lingkungan sekitar kita. Dalam hal ini anak akan dapat berkreasi melalui hal baru yang diketahui anak. Kreatifitas anak ini dapat dikembangkan melalui bermain dengan berbagai media sesuai dengan stimulasi yang tepat. Media yang digunakan saat memberikan materi pada anak sangat berpengaruh terhadap penyerapan materi. Media yang menarik dapat menciptakan suasana belajar menyenangkan sehingga dapat meningkatkan kemampuan seni anak di TK Negeri Kepanjenkidul I Kota Bitar perlu terus diupayakan. Berdasarkan hasil pengamatan dan hasil evaluasi dari proses belajar anak kelompok A, Semester II di TK Negeri Kepanjenkidul I Kota Blitar Tahun pelajaran 2019-2020 ternyata masih banyak anak yang belum mampu dalam 
kemampuan seni terutama pada kegiatan melukis dengan lilin. Hal ini terlihat ketika melakukan kegiatan melukis /menggambar, kelihatan jari-jari tangan anak masih kaku dalam menyelesaikan setiap kegiatan khususnya kegiatan kemampuan seni melalui kegiatan melukis dengan lilin.

Dari permasalahan tersebut diatas pada kemampuan melukis dengan menggunakan media lilin masih terlihat rendah, hal ini disebabkan karena: 1). anak belum dapat memahami tugas dengan media yang diberikan sehingga perkembangan kemampuan seni melukis belum sepenuhnya berkembang ketika menggunakan media lilin, 2) guru kurang kreatif dalam menyampaikan media pembelajaran sehingga terlihat monoton, 3) dalam penyampaian materi guru selalu menggunakan metode ceramah sehingga membuat anak menjadi jenuh, 4) adanya pengelolaan kelas yang kurang bervariasi dan menyenangkan anak, 5) media atau alat peraga masih kurang menarik bagi anak. Dari pemaparan di atas, maka peneliti memfokuskan pada pemecahan masalah untuk peningkatan kemampuan seni anak melalui melukis dengan mengadakan penelitian tindakan kelas yang berjudul: Peningkatan Kemampuan Seni Pembelajaran Melukis Dengan Lilin Pada Anak Kelompok A TK Negeri Kepanjenkidul I Kota Blitar Semester II Tahun Pelajaran 2019-2020.

\section{METODE PENELITIAN}

Penelitian ini dirancang dengan rancangan penelitian tindakan kelas (PTK). Menurut Akbar (2009), bahwa PTK adalah proses pemecahan masalah pembelajaran yang ada di dalam kelas. Proses pemecahan masalah tersebut dilakukan secara bersiklus dengan tujuan untuk meningkatkan kualitas pembelajaran dan hasil pembelajaran di kelas tertentu. Model siklus yang digunakan dalam penelitian ini adalah model yang dikembangkan oleh Kemis dan MC, Taggart dalam (Akbar Sa'dun,2009). Dimana konsep penelitian tindakannya menggunakan perangkat yang yang terdiri dari empat komponen, yaitu: perencanaan, tindakan, pengamatan (observasi) dan refleksi. Dari keempat komponen itu merupakan rangkaian dari satu siklus. Bagan dari PTK sebagai berikut:

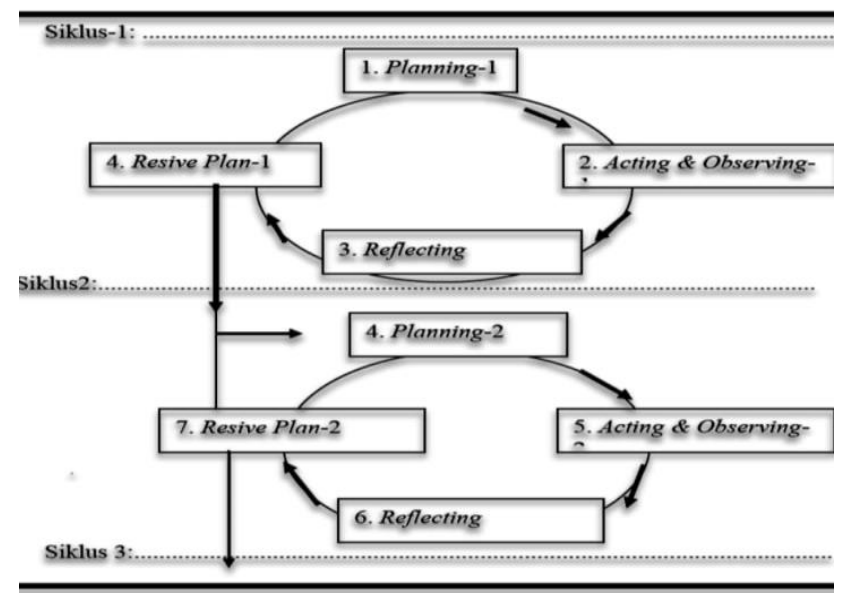

Bagan 1. Alur Penelitian Tindakan Kelas

Pada kegiatan Penelitian Tindakan Kelas di atas dapat dijelaskan sebagai berikut : Pada tahap ini perencanaan peneliti (1) Menentukan tema, sub tema, dan menentukan masalah yang terjadi didalam proses kegiatan pembelajaran,(2) Penyusunan RPPH yang dirancang dengan menggunakan media melukis dengan lilin,(3) Mempersiapkan media pembelajaran,(4) Membuat instrument yang akan digunakan dalam PTK. Pada tahap pelaksanaan merupakan penerapan pada seluruh perencanaan kegiatan dengan media melukis dengan lilin. dalam tahap ini pengamat mulai melakukan pemantauan terhadap tindakan peneliti. Pengamatan dilakukan melalui observasi pelaksanaan proses kegiatan pembelajaran, dan mencatat sejumlah masalah yang timbul pada waktu pembelajaran. Sedangkan pada tahap refleksi, merupakan tahap untuk mengkaji secara menyeluruh tindakan yang telah dilakukan berdasarkan data yang ada. Pada 
tahap ini peneliti membandingkan masalah yang muncul sebelum diberikan masalah yang dihadapi setelah pemberian tindakan.

\section{HASIL DAN PEMBAHASAN}

\section{Hasil}

Penelitian tindakan kelas yang dilakukan oleh peneliti bertujuan untuk mengembangkan kemampuan seni anak kelompok A di TK Negeri Kepanjenkidul I Kota Blitar Tahun Pelajaran 2019-2020. Hasil penelitian dapat dilihat pada table 1 sebagai berikut:

Tabel 1. Lembar Penilaian Kegiatan Melukis Dengan Lilin Pada Pra Tindakan

\begin{tabular}{|c|l|c|}
\hline No & \multicolumn{1}{|c|}{ Komponen } & Penilaian \\
\hline 1. & Bentuk goresan & $18,2 \%$ \\
\hline 2. & Bentuk hasil lukisan & $49,9 \%$ \\
\hline 3. & Kerapihan & $18,2 \%$ \\
\hline 4. & Penguasan dengan warna & $13,6 \%$ \\
\hline & Rata-rata & $31,8 \%$ \\
\hline
\end{tabular}

Dari hasil penelitian ini menjelaskan bahwa sebelum melakukan tindakan pada siklus I, peneliti melakukan observasi prasiklus dengan melakukan pengamatan untuk mengetahui perkembangan kemampuan seni anak sebelum dilaksanakan tindakan. Tahap prasiklus ini dilakukan pada hari Senin, 20 Januari 2020. Hasil yang diperoleh pada kemampuan seni sebelum menerapkan kegiatan melukis dengan lilin dapat dilihat pada table 1 dengan nilai ratarata pada prosentase perkembangan kemampuan seni anak sebelum diadakan tindakan adalah $31,8 \%$, itu artinya bahwa kemampuan seni anak masih belum berkembang. Sehingga perlu diadakan perbaikan di siklus I.

\section{Siklus I}

Dari kegiatan yang dilaksanakan di siklus I tersebut maka peneliti dapat mengamati dan menghitung prosentase rata-rata kemampuan seni anak pada kegiatan melukis dengan lilin. mencapai 57,8\%. Dengan melihat hasil tersebut berarti kemampuan seni anak sudah mulai berkembang.

Tabel 2. Lembar Penilaian Kegiatan Melukis Dengan Lilin Pada Siklus I

\begin{tabular}{|c|l|c|}
\hline No & \multicolumn{1}{|c|}{ Komponen } & Penilaian \\
\hline 1. & Bentuk goresan & $54,3 \%$ \\
\hline 2. & Bentuk hasil lukisan & $53,5 \%$ \\
\hline 3. & Kerapihan & $52,2 \%$ \\
\hline 4. & Penguasan dengan warna & $55,6 \%$ \\
\hline & Rata-rata & $57,8 \%$ \\
\hline
\end{tabular}

\section{Siklus II}

Adapun untuk pembelajaran melalui kegiatan melukis dengan lilin di kelompok A dalam satu kelas sudah meningkat $81,5 \%$. Hasil peningkatan dapat dilihat dari prosentase kemampuan seni yang diperoleh anak. Prosentase peningkatan tersebut telah melebihi prosentase keberhasilan yang telah dientukan oleh peneliti yaitu $75 \%$

Tabel 2 Lembar Penilaian kegiatan melukis dengan lilin Pada Siklus II

\begin{tabular}{|c|l|c|}
\hline No & \multicolumn{1}{|c|}{ Komponen } & Penilaian \\
\hline 1. & Bentuk goresan & $80,2 \%$ \\
\hline 2. & Bentuk hasil lukisan & $82,3 \%$ \\
\hline 3. & Kerapihan & $80,1 \%$ \\
\hline 4. & Penguasan dengan warna & $83,4 \%$ \\
\hline & Rata-rata & $81,5 \%$ \\
\hline
\end{tabular}


Berdasarkan table 2, maka dapat menunjukkan penilaian hasil akhir siklus II mencapai skor $81,5 \%$. Hasil ini menunjukkan bahwa kemampuan seni kegiatan melukis sudah memenuhi standar yang ditetapkan peneliti yaitu minimal 75\%, maka oleh peneliti dikatakan berhasil/tuntas. Pada tabel 3 adalah perbandingan hasil belajar anak dari pra tindakan sampai pada siklus II.

Tabel 3. Perbandingan Hasil Belajar Anak Pra Tindakan Dan Siklus Ii

\begin{tabular}{|l|l|c|c|c|}
\hline \multirow{2}{*}{ No } & \multicolumn{2}{|c|}{ Komponen } & \multicolumn{3}{|c|}{ Penilaian } \\
\cline { 3 - 5 } & & $\begin{array}{c}\text { Pra } \\
\text { Tindakan }\end{array}$ & Siklus I & Siklus II \\
\hline 1. & Bentuk goresan & $18,2 \%$ & $54,3 \%$ & $80,2 \%$ \\
\hline 2. & Bentuk hasil lukisan & $49,9 \%$ & $53,5 \%$ & $82,3 \%$ \\
\hline 3 & Kerapihan & $18,2 \%$ & $52,2 \%$ & $80,1 \%$ \\
\hline 4. & Penguasan dengan warna & $13,6 \%$ & $55,6 \%$ & $83,4 \%$ \\
\hline & Rata-rata & $31,8 \%$ & $57,8 \%$ & $81,5 \%$ \\
\hline
\end{tabular}

Melihat hasil dari table diatas, maka dapat disimpulkan bahwa kemampuan seni anak dalam pembelajaran melukis dengan lilin di TK Negeri Kepanjenkidul I Kota Blitar meningkat menjadi 23,7\% Pada pelaksanaan pra tindakan terlihat masih belum berjalan secara maksimal. Hal ini dilihat bahwa pada pra tindakan melalui kegiatan melukis dengan lilin ternyata pengelolaan kelas masih kurang kondusif, adanya penjelasan guru yang terlalu cepat sehingga masih belum dapat dipahami anak, serta dalam pemilihan metode masih kurang tepat.

Berdasarkan hasil dari analisis melalui observasi anak selama kegiatan berlangsung maka dapat diketahui bahwa anak masih belum mampu/ belum bisa melaksanakan tugas yang diberikan oleh guru dalam kegiatan melukis dengan lilin sehingga mereka masih merasa kesulitan untuk mengerjakannya. Setelah dilihat ternyata perolehan nilai yang didapat dari kegiatan anak terlihat masih sekitar 31,8\% dari data pra tindakan yang akan dijadikan sebagai pertimbangan dalam pelaksanaan pembelajaran siklus I. Siklus I dilaksanakan pada hari Senin,4 Pebruari 2020 di TK Negeri Kepanjenkidul I pada anak kelompok A. Pada waktu pelaksanaan siklus I dan siklus II, guru sudah menyusun langkah-langkah agar penerapan metode demonstrasi dapat berjalan secara maksimal. Sesuai dengan metode demonstrasi yang digunakan yaitu dengan cara menunjukkan dan mempraktekkan langkah-langkah cara melukis dengan lilin sehingga anak dapat memahami dengan jelas dan dapat melakukannya dengan benar. Langkah-langkah pelaksanaan yang dilakukan antara lain: (a) mengenalkan nama media, alat dan bahan yang akan digunakan dalam melukis. (b) guru menyebutkan nama alat transportasi sesuai dengan tema dan sub temanya yang akan digunakan untuk melukis. (c) guru memperlihatkan cara-cara melukis dengan lilin kemudian diusap dengan kuas dan pewarna agar terlihat hasil gambarnya. (d) guru kemudian meminta anak untuk menirukan melukis dengan menggunakan lilin. (e) guru mengamati kegiatan yang sedang mereka lakukan sambil membimbing anak yang mengalami kesulitan ketika sedang menggoreskan lilin di atas kertas sambil memberikan motivasi (f) guru kemudian memberikan reward sebagai hadiah bagi anak yang telah selesai mengerjakan tugasnya.

Pada sikuls II pembelajaran melukis dengan lilin yang dilakukan anak sudah berjalan dengan baik dan tidak lagi mengalami kesulitan, sehingga ketika guru mengajar dengan memberikan materinya pada proses pembelajaran sudah sesuai dengan strategi dan metode demonstrasi dengan langkah-langkah yang tepat pada pembelajaran yang inovatif untuk meningkatkan kemampuan seni dalam kegiatan melukis dengan lilin. Ketika melakukan pengumpulan data- data dari kegiatan di siklus I, maka peneliti dapat melaksanakan perbaikan pembelajaran di siklus II berdasarkan hasil yang telah disepakati pada kegiatan sebelumnya. Adapun pelaksanaan siklus II dilaksanakan pada hari Senin, 2 Maret dan 19 Maret 2020.

Siklus II pelaksanaan pembelajaran sama dengan yang dilakukan di siklus I, yaitu penerapan langkah metode demonstrasi untuk meningkatkan kemampuan seni anak pada kegiatan melukis dengan lilin. dalam pelaksanaannya dibagi menjadi 3 kelompok kecil, dimana 
setiap kelompok terdiri dari 5 anak agar guru lebih mudah dalam membimbing dan anak juga mudah mendapatkan pemahaman yang lebih baik. Hasil yang diperoleh mengalami peningkatan dari pada pembelajaran sebelumnya.

Dari data rekapitulasi kegiatan belajar anak, maka dapat diketahui bahwa terdapat peningkatan pada hasil belajar anak dalam kemampuan seni melalui kegiatan melukis dengan lilin. Pelaksanaan pembelajaran diawali dengan cara guru memberikan penjelasan langkahlangkah cara melukis dengan menggunakan lilin, setelah itu guru meminta anak untuk melaksanakan tugas seperti yang telah dicontohkan guru. Pada kegiatan melukis ini masih banyak anak yang belum memahami dan merasa kesulitan dalam melaksanakan kegiatan tersebut sehingga sebagian besar banyak anak yang belum dapat menyelesaikan tugasnya. Sehingga peneliti harus melaksanakan perbaikan di siklus II.

Di siklus I guru menerapkan kegiatan pembelajaran dengan menggunakan langkah metode demonstrasi untuk meningkatkan kemampuan seni melalui kegiatan melukis dengan lilin. Ada beberapa anak yang terlihat masih belum tuntas dalam melaksanakan kegiatan tersebut, terlihat dari pra tindakan mencapai $31,8 \%$. Ketuntasan belajar di siklus I mencapai $57,8 \%$, walaupun masih berada dibawah ketuntasan yang telah ditetapkan sebagai perbaikan, maka dapat dilaksanakan di siklus II dimana anak dalam kegiatan melukis masih memerlukan dorongan, motivasi, serta bimbingan agar dapat menjadi lebih baik lagi.

Menurut Arikunto (1998) bahwa anak dapat dikatakan tuntas apabila hasil tugas yang diperoleh mencapai lebih dari 75\%. Dan ketika diamati di siklus II ternyata hasil belajar kegiatan anak yang telah meningkat menjadi 81,5\% dari 15 anak dan mengalami peningkatan 23,7\%. Dari hasil penjelasan diatas, maka dapat disimpulkan bahwa kemampuan seni anak dalam pembelajaran kegiatan melukis dengan lilin di kelompok A TK Negeri Kepanjenkidul I Kota Blitar meningkat sebesar 23,7\%.

Dari hasil penelitian yang telah dilaksanakan, dalam meningkatkan kemampuan seni anak melalui kegiatan melukis dengan menggunakan lilin pada anak kelompok A di TK Negeri Kepanjenkidul I Kota Blitar dari mulai pra tindakan, siklus I, siklus II setelah diamati mengalami peningkatan. Hal ini dapat dilihat dari hasil penilaian ketuntasan belajar anak seperti pada table di bawah ini:

Tabel 4. Hasil Penilaian Kemampuan Seni Anak Kelompok A Mulai dari Pra Tindakan sampai Siklus II

\begin{tabular}{|c|c|c|c|c|}
\hline No & Hasil Penilaian & $\begin{array}{c}\text { Pra } \\
\text { Tindakan }\end{array}$ & $\begin{array}{c}\text { Tindakan } \\
\text { Siklus I }\end{array}$ & $\begin{array}{c}\text { Tindakan } \\
\text { Siklus II }\end{array}$ \\
\hline 1 & $18,2 \%$ & $54,3 \%$ & $80,2 \%$ \\
\hline 2 & $49,9 \%$ & $53,5 \%$ & $82,3 \%$ \\
\hline 3 & $18,2 \%$ & $52,2 \%$ & $80,1 \%$ \\
\hline 4 & $13,6 \%$ & $55,6 \%$ & $83,4 \%$ \\
\hline $\begin{array}{c}\text { Presentase Ketuntasan } \\
\text { Belajar }\end{array}$ & $31,8 \%$ & $57,8 \%$ & $81,5 \%$ \\
\hline
\end{tabular}

\section{Pembahasan}

Dari uraian diatas maka dapat diketahui bahwa melalui kemampuan seni hasil penilaian anak dalam pembelajaran melukis dengan lilin sebelum dilakukan tindakan mencapai 31,8\%. Ini berarti kriteria ketuntasan belajar yang diharapkan masih belum tercapai, sehingga perlu diadakan perbaikan pembelajaran di siklus II dengan mengacu pada refleksi siklus I.

Pada siklus II anak sudah mulai menunjukkan adanya peningkatan, baik dari hasil maupun proses. Anak mulai tertarik dan aktif dalam melakukan kegiatan melukis dengan lilin. Mereka mulai berkreasi dengan hasil imajinasinya sendiri, dan hasil goresan pada lukisan tersebut semakin tampak jelas bentuknya dan menggorespun juga sudah terlihat rapi. Namun masih ada beberapa anak yang terlihat bosan dengan kegiatan tersebut. Hasil penilaian unjuk kerja dengan metode demosntrasi di siklus II ini mengalami peningkatan yang signifikan yaitu 
dengan prosentase ketuntasan $81,8 \%$. Oleh karena itu pada siklus II ini kriteria ketuntasan belajar telah tercapai sehingga tidak diperlukan lagi perbaikan dalam pembelajaran selanjutnya. Melihat hasil observasi, maka dapat dievaluasi bahwa langkah-langkah yang telah dilaksanakan mampu mencapai tujuan yang diharapkan. Dengan demikian maka penerapan kemampuan seni pada kegiatan melukis dengan menggunakan lilin anak kelompok A di TK Negeri Kepanjenkidul I Kota Blitar sudah mengalami peningkatan yang sangat baik dan memenuhi standar yang telah ditetapkan. Berikut adalah grafik gambar prosentase peningkatan kemampuan seni melalui kegiatan melukis dengan lilin pada anak kelompok A TK Negeri Kepanjenkidul I Kota Blitar.

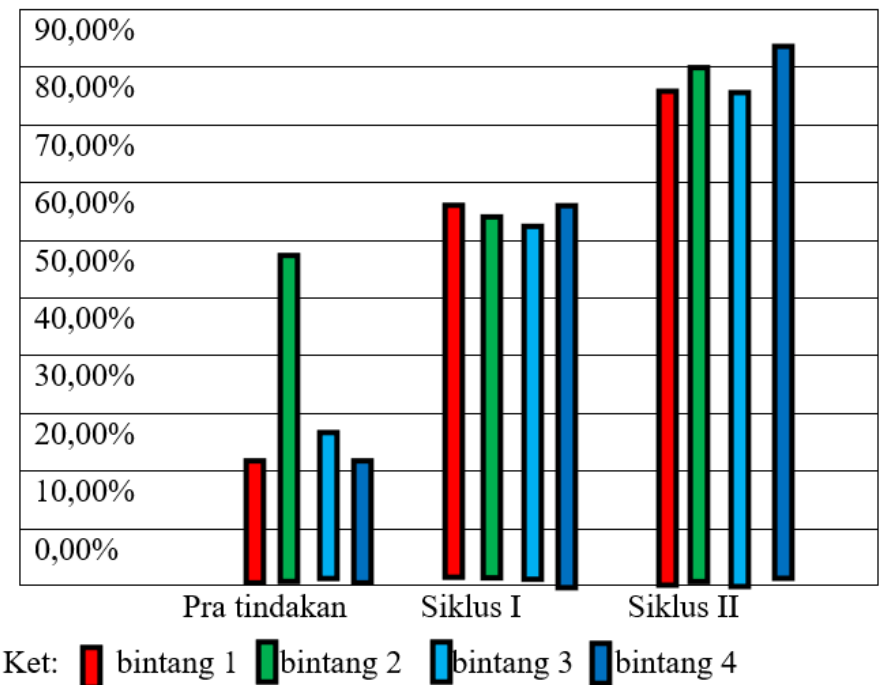

\section{Gambar 1. Peningkatan Kemampuan Seni Melalui Kegiatan Melukis Dengan Lilin Pada Anak Kelompok A TK Negeri Kepanjenkidul I Kota Blitar}

Melihat gambar grafik diatas, dengan merujuk hasil yang dikutip menurut Iswantiningtyas Veny (2017) dalam artikelnya menjelaskan bahwa prosentase ketuntasan belajar kemampuan seni anak dalam kegiatan melukis dengan lilin mengalami peningkatan dari pra tindakan sampai siklus II. Pada pra tindakan penilaian mencapai 31,8\%, kemudian dilakukan tindakan pada siklus I mengalami peningkatan sebesar $26 \%$ sehingga menjadi $57,8 \%$. Dari siklus I ke siklus II mengalami peningkatan sebesar 23,7\% sehingga menjadi $81,5 \%$ dari ketentuan jumlah yang ditetapkan peneliti yaitu $75 \%$.

\section{KESIMPULAN}

Berdasarkan hasil dari penelitian tindakan kelas yang dilaksanakan melalui beberapa tindakan dari siklus I dan siklus II, maka dapat diambil kesimpulan bahwa dengan metode demonstrasi melalui kegiatan melukis dengan lilin dapat mengembangkan kemampuan seni anak. Hal ini ditunjukkan dengan adanya peningkatan dari rata-rata prosentasi dari perkembangan seni anak sebelum melakukan tindakan $31,8 \%$, siklus I mencapai $57,8 \%$, siklus II mencapai $81,5 \%$ telah mengalami kenaikan sebesar $23,7 \%$. Hampir semua anak mampu mengenal peralatan yang digunakan untuk melukis serta langkah-langkah yang benar dalam melakukan kegiatan melukis dengan lilin. Penerapan melalui kegiatan melukis dengan lilin ini merupakan suatu metode pembelajaran yang dapat menciptakan kreatifitas dan imajinasi anak dalam meningkatkan kemampuan seni anak yang bersifat menyenangkan. Dengan demikian maka dapat disimpulkan bahwa kemampuan seni anak dapat dikembangkan dan melalui kegiatan melukis dengan lilin pada anak kelompok A di TK Negeri Kepanjenkidul Kota Blitar Semester II pada Tahun Pelajaran 2019-2020. 


\section{DAFTAR PUSTAKA}

Arikunto, Suharsimi. (1998). Prosedur Penelitian; Suatu Pendekatan Praktik. Jakarta: PT Rineka Cipta

Akbar, Sa'dun. (2009). Penelitian Tindakan Kelas: Jakarta: Universitas Terbuka

E.Muharam, \& S.W. (1993). Pendidikan Kesenian II (Seni Rupa). Jakarta: Depdikbud

Hajar Pamadhi dan Sukardi. (2010). Seni Ketrampilan Anak. Jakarta: Universitas Terbuka

Iswantiningtyas Veny. (2017). Meningkatkan Kemampuan Motorik Halus melalui Media Lukisan Pada Anak Kelompok B TK PGRI Sumberbendo Kecamatan Pucanglaban Kabupaten Tulungagung Tahun Pelajaran 2016/2017

Moeslichatoen. (2004). Dalam Metode Pengajaran. Jakarta: Rineka Cipta

Soedarso, SP. (1987). Tinjauan Seni: Sebuah Pengantar untuk Apresiasi Yogyakarta: Saku Dayar Sana

Slamet Suyanto. (2005). Pembelajaran Untuk Anak TK. Jakarta. Depdiknas

Undang- Undang RI Nomor 20 Tahun 2003 tentang Sistem Pendidikan Nasional 